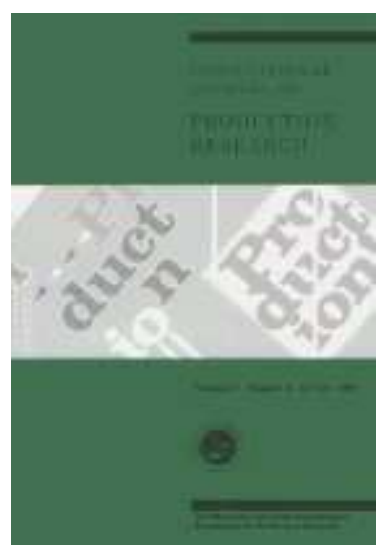

\title{
SUPPLY CHAIN RISK MANAGEMENT AND ITS MITIGATION IN A FOOD INDUSTRY
}

\begin{tabular}{|r|l|}
\hline Journal: & International Journal of Production Research \\
\hline Manuscript ID: & TPRS-2010-IJPR-0912.R1 \\
\hline Manuscript Type: & Original Manuscript \\
\hline Author: & 17-Jan-2011 \\
\hline Complete List of Authors: & $\begin{array}{l}\text { Diabat, Ali; MASDAR Institute of Science and Technology, } \\
\text { Engineering Systems and Management } \\
\text { Kannan, Prof. Govindan; University of Southern Denmark, } \\
\text { Department of Business and Economics } \\
\text { Panikar, Vinay; National Institution of Technology, Mechanical } \\
\text { Engineering }\end{array}$ \\
\hline Keywords: & SUPPLY CHAIN MANAGEMENT, RISK MANAGEMENT \\
\hline Keywords (user): & \\
\hline
\end{tabular}

\section{SCHOLARONE} Manuscripts 
SUPPLY CHAIN RISK MANAGEMENT AND ITS MITIGATION IN A FOOD INDUSTRY

\author{
${ }^{1}$ Kannan Govindan ${ }^{2}$ Ali Diabat $\quad{ }^{3}$ Vinay V Panicker \\ 1 - Department of Business and Economics, University of Southern Denmark, Odense, Denmark. \\ 2 - Engineering Systems and Management, Masdar Institute of Science and Technology, Abu Dhabi, UAE \\ 3 - Department of Mechanical Engineering, National Institute of Technology Calicut, Calicut, India \\ E.mail: gov@sam.sdu.dk
}

\begin{abstract}
The food supply chain is the domain in this work which suffers a lot of uncertainty in its functioning. The paper discusses the various research works in the area of Supply Chain Risk Management (SCRM). The main objective of the proposed work is to create a model which analyzes the various risks involved in a food supply chain with the help of Interpretive Structural Modeling (ISM) tool. The types of risks are clustered in five categories and the risk mitigation is discussed. The model developed is validated with the help of case study on a food products manufacturing firm (RMK food products) in the southern part of India. The various types of risks involved in the food industries were selected based on the literature study and in consultation with the experts in food industry. This work helps the manager to identify the risks having high driving power and low dependency and vice versa.
\end{abstract}

Keywords: Supply Chain Risk Management (SCRM); Food supply chain; Interpretive Structural Modeling (ISM); Risk mitigation 


\title{
SUPPLY CHAIN RISK MANAGEMENT IN THE FOOD INDUSTRY
}

\begin{abstract}
We create a model which analyzes the various risks involved in a food supply chain with the help of Interpretive Structural Modeling (ISM). The various types of risks were identified based on a review of the literature and in consultation with experts in the food industry. The types of risks are clustered into five categories and risk mitigation is discussed. The model developed is validated with the help of a case study involving a food products manufacturing firm.
\end{abstract}

Keywords: Supply Chain Risk Management (SCRM); Food supply chain; Interpretive Structural Modeling (ISM); Risk mitigation 


\subsection{INTRODUCTION}

Supply chain risk may result from unexpected variations in capacity constraints, or from breakdowns, quality problems, fires or even natural disasters at the supplier end (Blackhurst et al. 2005, Yang and Yang, 2010). A failure of any one element in a supply chain potentially causes disruptions for all partnering companies upstream and downstream (Yang and Yang, 2010). For example, the leading telecom company Ericsson was affected seriously by a fire at one of its suppliers. (Wall Street Journal, 2001).

The vulnerability of a supply chain increases with increasing uncertainty (Svensson, 2000), and it increases even further if companies, by outsourcing, have become dependent on other organizations. The greater uncertainties in supply and demand, increasing globalization of the market, shorter and shorter product and technology life cycles, and the increased use of manufacturing, distribution and logistics partners resulting in complex international supply network relationships have led to increased exposure to risks in the supply chain.

Although many risks exist in business, three have applicability to the supply chain, namely supply risks, operations risks and demand risks. Supply risks reside in the course of movement of materials from suppliers to the firm and include the reliability of suppliers, and considerations such as single versus multiple sourcing and centralized versus decentralized sourcing. Operational risks affect the firm's internal ability to produce goods and services, ultimately affecting the profitability of the company, and may result from a breakdown in manufacturing or processing capability and/or changes in technology. Demand risks reside in the movement of goods from the firm to the customers, and include the risk of obsolescence, stock-outs, and/or over-inventory.

The development of effective strategies for managing risk hinges on first understanding the sources of risk and their relationships. In this paper we model the various risks that can have an impact on the food supply chain. The main objectives of this paper are:

(1) to identify and rank the risks involved in food supply chains;

(2) to determine the interactions among identified risks; and

(3) to understand the managerial implications of this research.

The paper is organized is follows. Section 2 surveys the literature on supply chain risks and their mitigation. Section 3 describes the solution methodology. Section 4 provides an overview of the company that is the subject of the case study, and applies the methodology developed in 
this paper to analyze the risks it faces in its food supply chain, followed by discussion and conclusions in Section 5.

\subsection{LITERATURE SURVEY}

Some of the classic techniques of risk management are: (1) prevention or lowering of risks through understanding; (2) controlling the impact of risk, so that even if an adverse event occurs, the impact is minimized; (3) mitigating risk by transferring it to other parties; (4) diversification of products; (5) risk pooling. Insurance provides one example of mitigating risk by transferring it to other parties. In this case the insurance company assumes the risk for a price.

Deloach (2000) defines business risk as "the level of exposure to uncertainties that the enterprise must understand and effectively manage as it executes its strategies to achieve its business objectives and create value". A measure of risk combines a measure of the probability of occurrence of each primary event with a measure of the consequences of that event. Quantitatively, risk can be calculated as the product of the probability of an event and the business impact (or severity) of that event.

A number of authors have studied supply chain risks or supply chain risk management. Norrman and Lindroth (2002) define supply chain risk management as collaborating with partners to deal with risks and uncertainties caused by, or impacting on, logistics-related activities or resources. Supply chain risk management (SCRM) can be defined as "the management of supply chain risks through coordination or collaboration among the supply chain partners so as to ensure profitability and continuity'" (Tang, 2006).

Jüttner et al. (2002) have observed that the use of the term "risk" can be confusing, and argue that risk should be separated from "risk (and uncertainty) sources" and "risk consequences" (risk impact). Risk sources are the environmental, organizational or supply chain related variables that cannot be predicted with certainty and that affect the supply chain outcome variables (Norrman and Jansson, 2004). Jüttner et al. (2002) organized the risk sources relevant for supply chains into three categories: (1) external to the supply chain (2) internal to the supply chain (3) network-related. Johnson (2001) classified risks into two categories: supply risks (e.g. capacity limitations, currency fluctuations and supply disruptions) and demand risks (e.g. seasonal imbalances, volatility of fads, new products). Zsidisin et al. (e.g.2000) considered 
supply risks related to design, quality, cost, availability, manufacturability, suppliers, legal and environmental issues, health and safety.

Chidambaram (2003) identified the steps involved in handling risk as risk classification, risk identification, risk calculation and implementation/validation. In the context of supply chain risk management, Juttner et al. (2003) consider the steps in handling risk as:

- Assessing risk sources in the supply chain

- Defining adverse consequences for the supply chain

- Identifying risk drivers and

- Mitigating risks for the supply chain

Tang (2006) divided risk into operational risks and disruption risks. Operational risks are associated with inherent uncertainties such as uncertain customer demand, uncertain supply, and uncertain cost, whereas disruption risks are associated with major disruptions caused by natural and man-made disasters such as earthquakes, floods, hurricanes, terrorist attacks, etc., or economic crises such as currency devaluation or strikes. He finds that the business impact associated with disruption risks is much greater than that of the operational risks. Tang (2006) associated supply chain risks with four management areas, namely supply management, demand management, product management, and information management, as illustrated in Figure 1. Supply management involves coordinating with upstream partners to ensure timely delivery of supplies. Demand management involves coordinating with downstream partners to influence demand in a beneficial manner. Product management involves modifying the product or process design so as to make it easier to ensure that supply meets demand. Information management involves an effort on the part of supply chain partners to improve their coordination, which may involve sharing various types of information that is available to individual supply chain partners.

There have been a number of key findings related to supply chain risk. Chopra and Sodhi (2004) found that risk reduction can be expensive; pooling forecasted risk across partners may reduce the cost of mitigating risks. Harland et al. (2003) developed a supply chain risk management tool and tested it on a case study. Johnson (2001) presented risk reduction methodologies and listed the lessons learned from managing supply chain risk. Other relevant literature on supply chain risk includes Huang et al. (2009), Yang and Yang (2010), Kumar et al. (2010), Lockamy III and McCormack (2010), Wu and Olson (2010) and Canbolat et al. (2008). 


\section{Insert Figure 1 here}

\subsection{SOLUTION METHODOLOGY}

As discussed above, handling risk involves four steps: risk classification, risk identification, risk calculation and implementation/validation. The purpose of risk classification is to have a collective viewpoint on the group of factors, in order to help to identify the sources of maximum risk. Risk identification enumerates the sources of risk. The purpose of risk calculation is to calculate the impact of various factors on the risk and may require the use of a decision support tool. Implementation and validation is the final step in risk management (Wu et. al., 2006).

Based on Yin's work on case study design (Yin, 2003) we adopt the holistic single case design, and use the methodology of Interpretive Structural Modeling (ISM) to provide insight. The mathematical foundations of the methodology can be found in (Harary et al., 1965), while the philosophical basis for the development of the ISM approach is presented in (Warfield, 1973). The ISM methodology was developed as a communication tool for complex situations. It has been used for policy analysis (Hart and Malone, 1974; Hawthorne and Sage, 1975; Brand et al., 1976; Kawamura and Christakis, 1976) and management research (Mandal and Deshmukh, 1994; You et al., 1994; Jharkharia and Shankar, 2004, 2005; Sushil, 2005; Bolaňos et al., 2005; Ravi et al., 2005; Kannan and Haq, 2007).

\section{Insert Table 1 here}

Despite the benefits of the ISM methodology, namely that it transforms unclear, poorly articulated models of systems into clear, well-defined models (Sage, 1977), it has certain drawbacks (Kannan and Haq, 2007). One drawback is that the model obtained may be influenced strongly by the bias of the person who is judging the variables, as the relations among the variables always depends on that person's knowledge and familiarity with the firm, its operations, and its industry. Another drawback is that in the ISM framework, no weights are associated with the variables to take into account their relative importance.

The various steps involved in the ISM methodology are given below (Kannan and Haq, 2007) and in the flow chart shown in Figure 2.

Step 1: The risks involved in the food supply chain under study are listed. 
Step 2: Based on the identified risks in Step 1, a contextual relationship is established among risks with respect to which pairs of remaining risks will be examined.

Step 3: A Structural Self-Interaction Matrix (SSIM) is developed, which indicates pairwise relationships among risks for the system under consideration.

Step 4: A Reachability Matrix is developed from the SSIM and the matrix is checked for transitivity. The transitivity rule states that if a variable ' $A$ ' is related to ' $B$ ' and ' $B$ ' is related to ' $\mathrm{C}$ ', then ' $\mathrm{A}$ ' is necessarily related to ' $\mathrm{C}$ '.

Step 5: The Reachability Matrix obtained in Step 4 is partitioned into different levels.

Step 6: Based on the reachability matrix, a directed graph is drawn and the transitive links are removed.

Step 7: The resultant digraph is converted into an ISM by replacing variable nodes with statements.

Step 8: The ISM model developed in Step 7 is checked for conceptual inconsistency and necessary modifications are made.

\section{Insert Figure 2 here}

\subsection{CASE STUDY}

\subsection{Overview of the company}

The company under study, RMK food products, is a leading producer of food products in south India. The company manufactures flours and powders for the household, and produces at least 20 different products. The firm obtains the required raw materials from around 7 suppliers. The manufactured packed food product is distributed in and around the state through a network of many distributors. The product reaches the customer with the help of retailers. An overview of RMK's supply chain, along with the associated risks, is shown in Figure 3.

\section{Insert Figure 3 here}

We now apply the framework developed above to analyse the supply chain risks for the company under study. 


\subsection{Identification of the various risks in the supply chain}

We begin by enumerating the risks for the company based on a review of the literature and consultation with industry experts.

\subsubsection{Macro level risks}

The macro level risks for the food supply chain are due to natural disasters, diseases like bird flu (mentioned earlier), political unrest in the region, terrorist attacks, government regulations, labor strikes and lack of skilled personnel.

\subsubsection{Demand management risks}

Demand management risk in a supply chain is connected to demand for the product. Demand for a product can change suddenly due to economic downturn, changes in customer tastes, failure to communicate with customers or an increase in the bargaining power of customers, or demand can become more volatile.

\subsubsection{Supply Management Risks}

Supply management risk in a supply chain is associated with obstacles at the supply end. A shortage in raw materials is a major reason for this risk. Other reasons include suppliers going bankrupt, a failure in communications between the client (in this case RMK food products) and a supplier, failure of the partnership, poor quality of the supplied goods, and delays at the supplier end.

\subsubsection{Product/Service Management Risks}

Product/service management risk is caused by maintaining an inventory level which is too high, thus increasing holding costs, or by underutilized capacity.

\subsubsection{Information Management Risks}

Information management risk in the supply chain is due to errors in forecasting the demand for the product, distortions in the information sharing and failures in IT systems.

For each risk type, a different risk mitigation strategy needs to be adopted (Oke and Gopalakrishnan, 2009). We use the risk mitigation strategies given in Table 2. Since many of the 
risks are associated with rare events, it takes a substantial amount of time to evaluate the proposed risk mitigation strategy.

\section{Insert Table 2 here}

\subsection{Development of Structural Self-Interaction Matrix (SSIM)}

A Structural Self-Interaction Matrix (SSIM) is a matrix indicating the pairwise relationships among the variables, in this case the risks in the food supply chain of the firm under consideration. We now develop the SSIM for the various risks identified above.

The symbols used to denote the direction of relationship between the risks are given below. For variables (in this case risks) $i$ and $j$, the (i,j) entry of the SSIM is ' $V$ ' if $i$ will help to alleviate $\mathrm{j}$; ' $A$ ' if $\mathrm{i}$ will be alleviated by $\mathrm{j}$, ' $\mathrm{X}$ ' if $\mathrm{i}$ and $\mathrm{j}$ help to alleviate each other, and ' $\mathrm{O}$ ' if there is no relation.

$$
\begin{aligned}
& \text { V - Risk } i \text { will help to alleviate Risk } j \text {; } \\
& \text { A - Risk } i \text { will be alleviated by Risk } j \text {; } \\
& \text { X - Risks } i \text { and } j \text { will help to alleviate each other; and } \\
& \text { O - Risks } i \text { and } j \text { are unrelated. }
\end{aligned}
$$

For example:

- Alleviating Macro level Risk helps to alleviate Information Management Risk (V); and

- Product/Service Management Risk will be alleviated by alleviating Information Management Risk (A).

Based on these relationships the SSIM is developed (Table 3).

\section{Insert table 3 here}

\subsection{Reachability Matrix}

The reachability matrix is derived from the structural self-interaction matrix (SSIM) developed in the previous step. The symbols are replaced with binary numbers 1 and 0 as follows.

- If the $(i, j)$ entry in the SSIM is $V$, the $(i, j)$ entry in the reachability matrix becomes 1 and the $(\mathrm{j}, \mathrm{i})$ entry becomes 0 . 
- If the $(i, j)$ entry in the SSIM is A, the $(i, j)$ entry in the reachability matrix becomes 0 and the $(\mathrm{j}, \mathrm{i})$ entry becomes 1 .

- If the $(i, j)$ entry in the SSIM is $X$, the $(i, j)$ entry in the reachability matrix becomes 1 and the $(\mathrm{j}, \mathrm{i})$ entry also becomes 1 .

- If the (i, j) entry in the SSIM is $\mathrm{O}$, the $(i, j)$ entry in the reachability matrix becomes 0 and the $(\mathrm{j}, \mathrm{i})$ entry also becomes 0 .

From the SSIM, the initial reachability matrix is developed using the above rules. The initial reachability matrix is given in Table 3a. The conceptual relationships among the risks corresponding to the initial reachability matrix are illustrated by the digraph shown in Figure 4. The final reachability matrix (Table $3 b$ ) is derived from the initial reachability matrix using the transitivity rule, which states that if a variable ' $A$ ' is related to ' $B$ ' and ' $B$ ' is related to ' $C$ ', then 'A' is necessarily related to ' $\mathrm{C}$ '. The final digraph is shown in Figure 5.

\section{Insert table 3 a here}

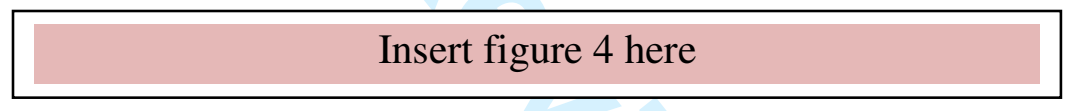

Insert table $3 b$ here

Insert figure 5 here

\subsection{Level partitions}

The reachability matrix obtained above in Section 4.3 is now partitioned into different levels. The reachability and antecedent sets for each risk (Warfield 1974) are found from the final reachability matrix (Table 3b). The reachability set for a particular risk consists of itself and the other risks which it may help to alleviate. The antecedent set for a particular risk consists of itself and the other risks which may help in alleviating it. The intersection set for each risk is the intersection of the corresponding reachability and antecedent sets. If the reachability set and the intersection set are the same then that risk is considered to be in level I and is given the top position in the ISM hierarchy (Kannan and Haq, 2007), meaning that this risk would not help in 
alleviating any other risk above its own level. With this partition, iteration 1 is completed. After the first iteration, the risks classified to level I are discarded and the above procedure is repeated on the remaining risks to determine the level II risks. These iterations are continued until the level of each risk has been determined. Applying this procedure to the reachability matrix obtained in Section 4.4 results in a partition in which product/service management risk is positioned at level I and forms the top level of the ISM hierarchy, while the remaining risks fall in level II. The results for iterations 1 and 2 are given in Tables $4 \mathrm{a}$ and $4 \mathrm{~b}$, respectively.

\section{Insert table $4 a$ \& $4 b$ here}

\subsection{Modeling of Food Supply Chain Risk}

The analysis above yields an ISM hierarchy in which product/service management risk is at level I (the top level) and all other risks are at level II. The resulting ISM model is illustrated in Figure 6.

\subsection{MICMAC ANALYSIS}

MICMAC stands for Matrice d'Impacts Croisés Multiplication Appliquée à un Classement, which means Cross-Impact Matrix Multiplication Applied to Classification. In MICMAC analysis, the dependence power and driver power of the variables are analysed. On the basis of the above study, the risks were classified into four sectors, namely autonomous, dependent, linkage and driver/independent. In the final reachability matrix in Table $3 \mathrm{~b}$, the driving power and dependence of each of the risks has been calculated. Risks having weak driver power and weak dependence will fall in sector I and are called autonomous elements. Risks having weak driver power but strong dependence will fall in sector II and are called dependent elements. Risks having both strong driver and dependence power will fall in sector III and are called linkage elements. These elements are unstable due to the fact that any action on these elements will affect the others and also may have a feedback effect on themselves. The driver or independent variables will fall in sector IV (Kannan and Haq, 2007).

\section{Insert figure 6 here}


Applying MICMAC analysis to the ISM model of the risks in the food supply chain of the firm under study yields the driving power and dependence power diagram shown in Figure 7. To illustrate how MICMAC analysis is done, it is observed from Table $3 b$ that the demand management risk has a driver power of 5 and dependence power of 4, therefore in Figure 7 this risk is positioned at coordinates which correspond to a driver power of 5 and a dependence power of 4 . The objective of classifying the risk is to analyze the driver power and dependence power of the risk.

The analysis shows that the macro level risk (1), demand management risk (2), supply management risk (3) and information management risk (5) have both strong driver power and dependence power and consequently fall in sector III, and are thus linkage elements. These risks can thus be considered as unstable risks and the actions taken on them may affect other risks. The product/service management risk (4) falls in sector I and is thus an autonomous element.

\section{Insert figure 7 here}

\subsection{DISCUSSION AND CONCLUSION}

The risks involved in the food supply chain of the firm under study were identified and strategies for mitigating these risks were proposed. This type of categorization is key to identify the relevant mitigation strategies to be adopted. Five categories of risk were identified, namely product/service management risk, macro level risk, demand management risk, supply management risk, and information management risk. An ISM model of the risks was constructed; the model placed product/service management risk at level I of the ISM hierarchy, suggesting that alleviating this risk would not help in alleviating any of the other risks, while the model placed all other risks at level II of the ISM hierarchy. MICMAC analysis revealed that product/service management risk had weak driving power and weak dependence power, and consequently was classified as an autonomous factor. All other risks had strong driving power and strong dependence power, and consequently were classified as linkage elements. The managerial implications of this analysis are that since product/service management risk is at the top of the ISM hierarchy and is also classified as an autonomous variable, management should assign high priority to mitigating this risk.

Based on this analysis, management has taken steps to mitigate the risks identified. To mitigate the demand management risk, the company plans to invest in good communication 
infrastructure to avoid any failure in communication. This will also help in mitigating the information management risk. Similarly demand forecasting is being done with the help of professionally qualified agencies so that the problems with volatile demand and declines in demand can be mitigated.

To avoid problems at the supplier end, the company has created a department for supplier selection and evaluation. The requirements of the company are conveyed earlier to the suppliers and steps were taken to reduce the likelihood of a shortage in raw materials. The company now places high priority on building long term partnerships with suppliers and seeks to ensure that the quality of the supplied goods are checked by the supplier before leaving the supplier.

The above model is based on the interpretive structural modeling methodology, which has its limitations. One limitation is that the model obtained is highly dependent on the judgements of the expert team, so the model must be validated. Structural equation modeling (SEM) can be used to validate the model.

There are several directions for future research. One is to validate the model obtained using structural equation modeling. It would also be of interest to determine the impact of a given mitigation strategy on the various partners in the supply chain.

\subsection{REFERENCES}

Blackhurst, J., Craighead, C.W., Elkins, D., Handfield, R.B., (2005), “An empirically derived agenda of critical research issues for managing supply-chain disruptions", International Journal of Production Research, Vol.43, No. 19, pp. 4067-4081.

Bolaňos, R., Fontela, R.E., Pastor, P., (2005), "Using interpretive structural modeling in strategic decision-making groups”, Management Decision, Vol. 43, No.5/6, pp. 877-895.

Brand Jr., D.H., Irwin, D.M. and Kawamura, K., (1976), "Implementation of interpretive structural modeling in a state-level planning context” In: Seventh Annual Pittsburgh Conference on Modeling and Simulation, Pittsburgh.

Canbolat, Y. B. , Gupta, G. , Matera, S. and Chelst, K.(2008) 'Analysing risk in sourcing design and manufacture of components and sub-systems to emerging markets', International Journal of Production Research, Vol. 46, No. 18, pp. 5145-5164.

Chidambaram, V. (2003), "Supply Chain Risk Management: A Study on Inbound Supply Risk Analysis", MS Thesis, Arizona State University, Department of Industrial Engineering. 
Chopra, S., Sodhi, M., 2004. Avoiding supply chain breakdown. Sloan Management Review Vol.46, No.1, pp. 53-62.

Christopher, M., (1992), “Logistics and Supply Chain Management”. Pitman, London.

Deloach, J.W. (2000), "Enterprise-wide Risk Management. Strategies for Linking Risk and Opportunities", Financial Times/Prentice-Hall, London.

F. Harary, R., Norman, Z. and Cartwright, D. (1965), "Structural Models: An Introduction to the Theory of Directed Graphs", Wiley, New York.

Faisal,M.N., Banwet,D.K. and Shankar,R.(2006), "Supply chain risk mitigation: modelling the enablers", Business Process Management Journal,Vol.12, No.4, pp. 535-52.

Harland, C., Brenchley, R. and Walker, H. (2003), "Risk in supply networks", Journal of Purchasing \& Supply Management, Vol. 9 No. 2, pp. 51-62.

Hart, W.L., Malone, D.W., (1974), “Goal setting for a state environmental agency” In: IEEE Conference on Decision and Control.

Hawthorne,R.W., and Sage,A.P.(1975), “On applications of interpretive structural modelling to Higher education program planning”, Socio-Economic Planning Sciences,Vol.9,No.1, pp.31-43.

Huang, H.-Y., Chou, Y.-C. and Chang, S. (2009), “A dynamic system model for proactive control of dynamic events in full-load states of manufacturing chains", International Journal of Production Research, Vol.47, No. 9, pp. 2485-2506.

Jedlicka,A. and Mayer,R.(1980), "Interpretive structural modelling cross-cultural uses”, Transactions on Systems, Man, and Cybernetics, Vol.10, No.1, pp.49-51.

Jharkharia, S., Shankar, R., (2004), "IT enablement of supply chains: modeling the enablers", International Journal of Productivity and Performance Management, Vol. 53, No.8, pp.700-712. Jharkharia, S., Shankar, R., (2005), "IT enablement of supply chains: understanding the barriers”, Journal of Enterprise Information Management, Vol. 18, No.1/2, pp. 11-27.

Johnson, M.E. (2001), "Learning from toys: lessons in managing supply chain risk from the toy industry”, California Management Review, Vol. 43 No. 3, pp. 106-24.

Jüttner, U., Peck, H. and Christopher, M. (2002), "Supply chain risk management: outlining an agenda for future research", in Griffiths, J., Hewitt, F. and Ireland, P. (Eds), Proceedings of the Logistics Research Network 7th Annual Conference, pp. 443-50. 
Kannan, G. and Haq, N.A. (2007), “Analysis of interactions of criteria and sub-criteria for the selection of supplier in the built-in-order supply chain environment", International Journal of Production Research, Vol.45, pp.1-22.

Kanungo, S., Duda, S. and Srinivas, Y.A .(1999), “A structured model for evaluating information Systems effectiveness", Systems Research and Behavioral Science, Vol.16, pp.495-518.

Kawamura, K., Christakis, A.N., (1976), "The role of structural modeling in technology assessment", In: Second International Congress on Technology Assessment.

Knight, F.H. (1921) Risk, Uncertainty, and Profit. Boston, MA: Hart, Schaffner \& Marx; Houghton Mifflin Company

Kumar, Sri Krishna, Tiwari, M. K. and Babiceanu, Radu F.(2010) 'Minimisation of supply chain cost with embedded risk using computational intelligence approaches', International Journal of Production Research, Vol.48, No.13, pp. 3717- 3739.

Lockamy III, Archie and McCormack, Kevin(2010) 'Analysing risks in supply networks to facilitate outsourcing decisions', International Journal of Production Research, Vol. 48, No. 2, pp. $593-611$

Mandal,A. and Deshmukh,S.G.(1993),"Vendor selection using interpretative structural modeling", International Journal of Operations \& Productions Management,Vol.14, No.6, pp.529.

Norrman, A. and Jansson, U. (2004), “Ericsson's proactive supply chain risk management approach after a serious sub-supplier accident", International Journal of Physical Distribution \& Logistics Management Vol. 34, No. 5, pp. 434-456

Norrman, A. and Lindroth, R. (2002), “Supply chain risk management: purchasers' vs planners' views on sharing capacity investment risks in the telecom industry", Proceedings of the 11th International Annual IPSERA Conference, Twente University, 25-27 March, pp. 577-95.

Oke, A. and Gopalakrishnan, M.,(2009), "Managing disruptions in supply chains: A case study of a retail supply chain", International Journal of Production Economics, Vol.118, pp.168-174. Porter, M. (1985), "Competitive Advantage”, The Free Press, New York. Ravi,V. and Shankar,R. (2004), “Analysis of interactions among the barriers of reverse logistics”, Technological Forecasting and Social Change, Vol.72, No.8, pp.1011-29. 
Ravi,V., Shankar,R. and Tiwari,M.K.(2005), "Productivity improvement of a computer Hardware supply chain”, International Journal of Productivity and Performance Management,Vol.54, No.4, pp.239-55.

Ritchie, R.L., Brindley, C.S., (2001), “The information—risk conundrum”, Journal of Marketing Intelligence and Planning, Vol. 19, No.1, pp. 29-37.

Sage,A.P.(1977), Interpretive Structural Modeling: Methodology for Large-Scale Systems, McGraw-Hill, NewYork,NY, pp.91-164.

Saxena,J.P., Sushil,J. and Vrat,P.(1992), "Hierarchy and classification of program plan elements using interpretive structural modeling: a case study of energy conservation in the Indian cement industry", Systems Practice,Vol.5, No.6, pp.651-70.

Scorecard: an integrated approach of interpretive structural modelling (ISM) and analytic Network process (ANP)", International Journal of Productivity and Performance Management, Vol.56, No.1, pp.25-69.

Sushil, (2005), "Interpretive matrix: a tool to aid interpretation of management and social research”, Global Journal of Flexible Systems Management, Vol. 6, No.2, pp. 27-30.

Svensson, G. (2000), "A conceptual framework for the analysis of vulnerability in supply chains", International Journal of Physical Distribution \& Logistics Management, Vol. 30 No. 9, pp. 731-50.

Tang, C.S. (2006), "Perspectives in supply chain risk management”, International Journal of Production Economics, Vol. 103, pp. 451-488

Thakkar,J., Deshmukh,S.G., Gupta,A.D., and Shankar,R.(2007),“Development of a Balanced Wall Street Journal (2001), "Trial by fire - a blaze in Albuquerque sets off major crisis for cellphone giants", 29 January.

Warfield, J.N. (1973), “An assault on complexity,” Battelle Memorial Inst., Columbus, Ohio, Battelle Monogr.

Warfield, J.W. (1974), "Developing interconnected matrices in structural modeling", IEEE Trans. Syst. Man Cybern., Vol. 4, No.1, pp. 51-81.

Wu, T., Blackhurst, J and Chidambaram, V.(2006), "A model for inbound supply risk analysis", Computers in Industry, Vol. 57, pp. 350-365 
Wu, Desheng Dash and Olson, David(2010) 'Enterprise risk management: a DEA VaR approach in vendor selection', International Journal of Production Research, Vol. 48, No.16, pp. 4919 4932,

Yang, B. and Yang, Y., (2010), "Postponement in supply chain risk management: a complexity perspective", International Journal of Production Research, Vol. 48, No.7, pp. 1901-1912.

Yin, R. K. (2003) Case study research: Design and methods ( $3^{\text {rd }}$ ed.). Thousand Oaks, cA: Sage.

You, N., Kato, Y., Kitaoka, M., 1994. Numerous data in hierarchy for knowledge concentrated in decision tree. Computers \& Industrial Engineering, Vol.27, No.1, pp.535-39.

Zsidisin, G., Panelli, A. and Upton, R. (2000), "Purchasing organization involvement in risk assessment, contingency plans, and risk management: an exploratory study", Supply Chain Management: An International Journal, Vol. 5, No. 4, pp. 187-97. 


\section{FIGURES:}

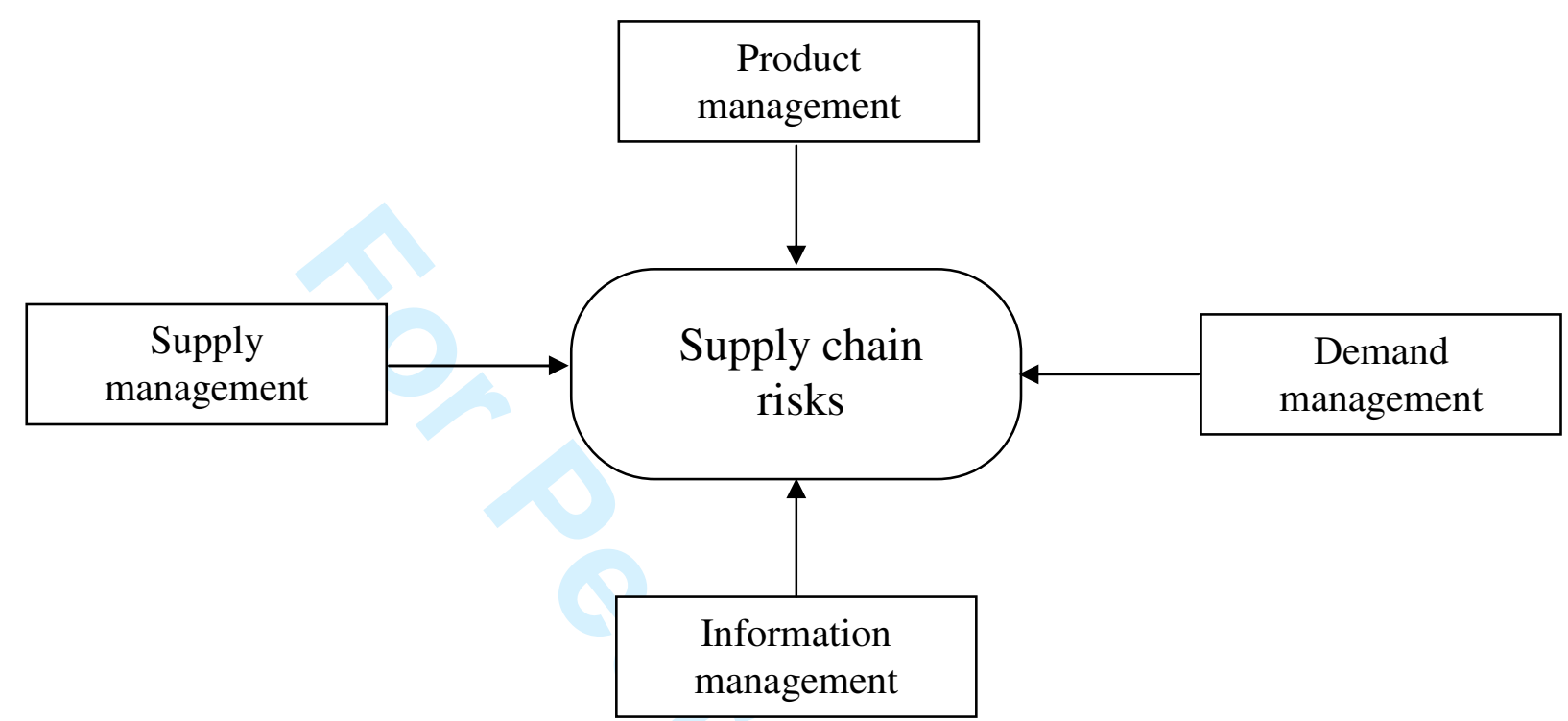

Figure 1: Basic approaches for risk mitigation (Source: Tang, 2006) 


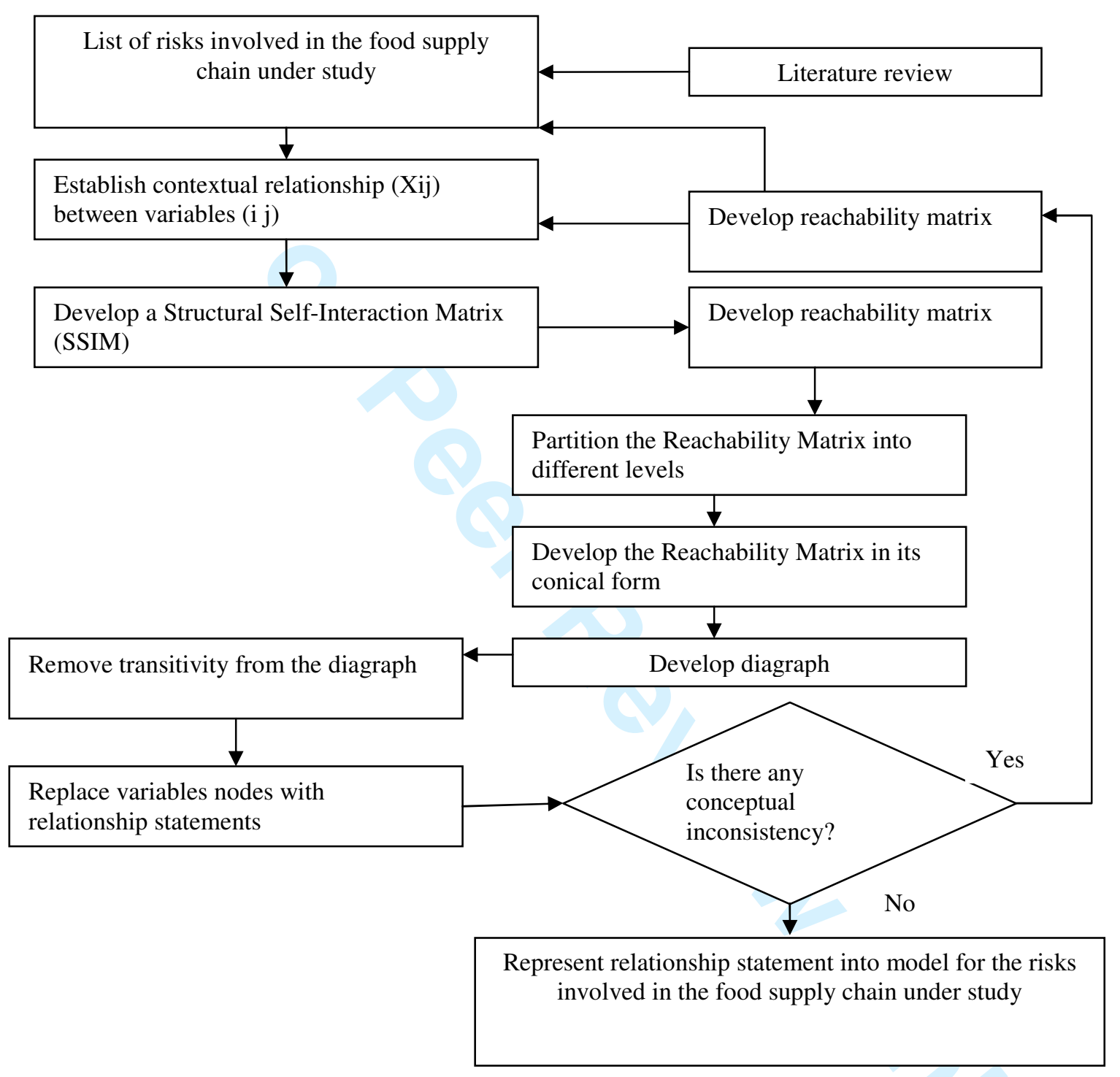

Figure 2: Flow chart for the ISM methodology 


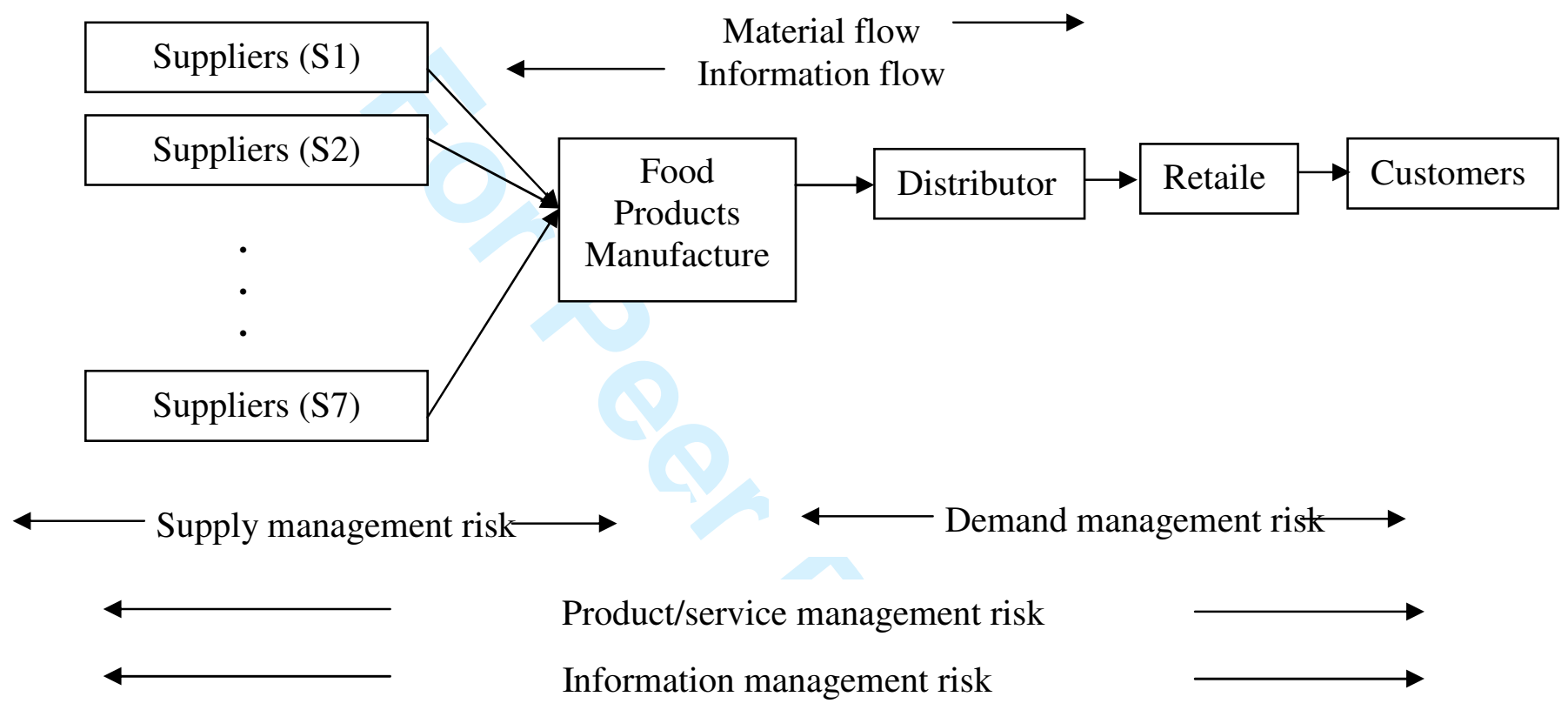

Figure 3: Overview of RMK's supply chain and its risks 


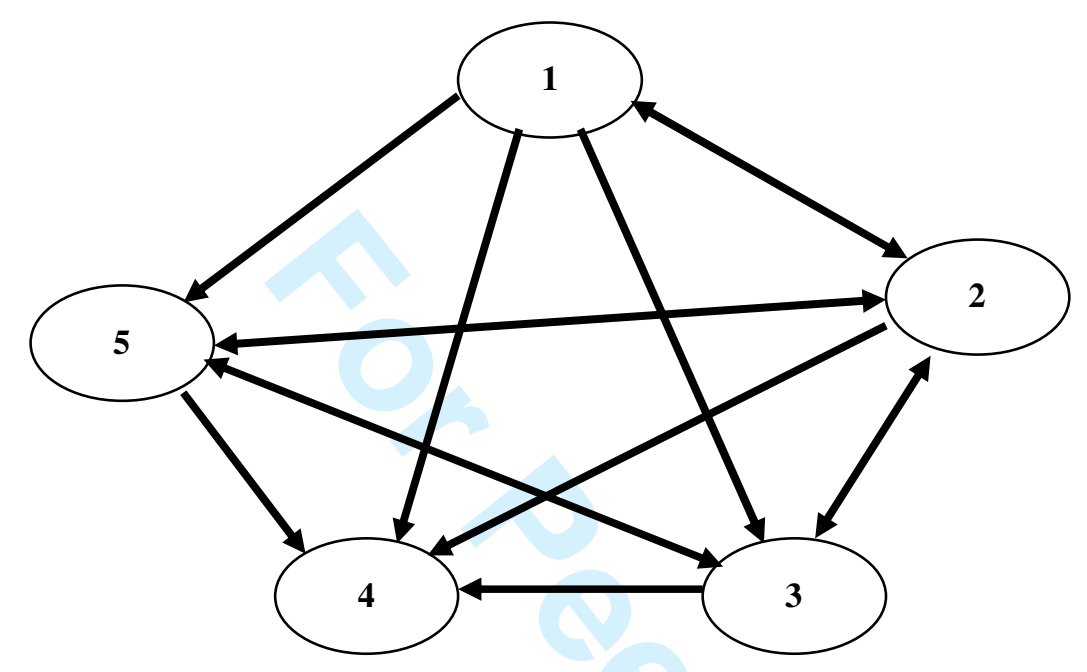

Figure 4: Initial digraph for the risks

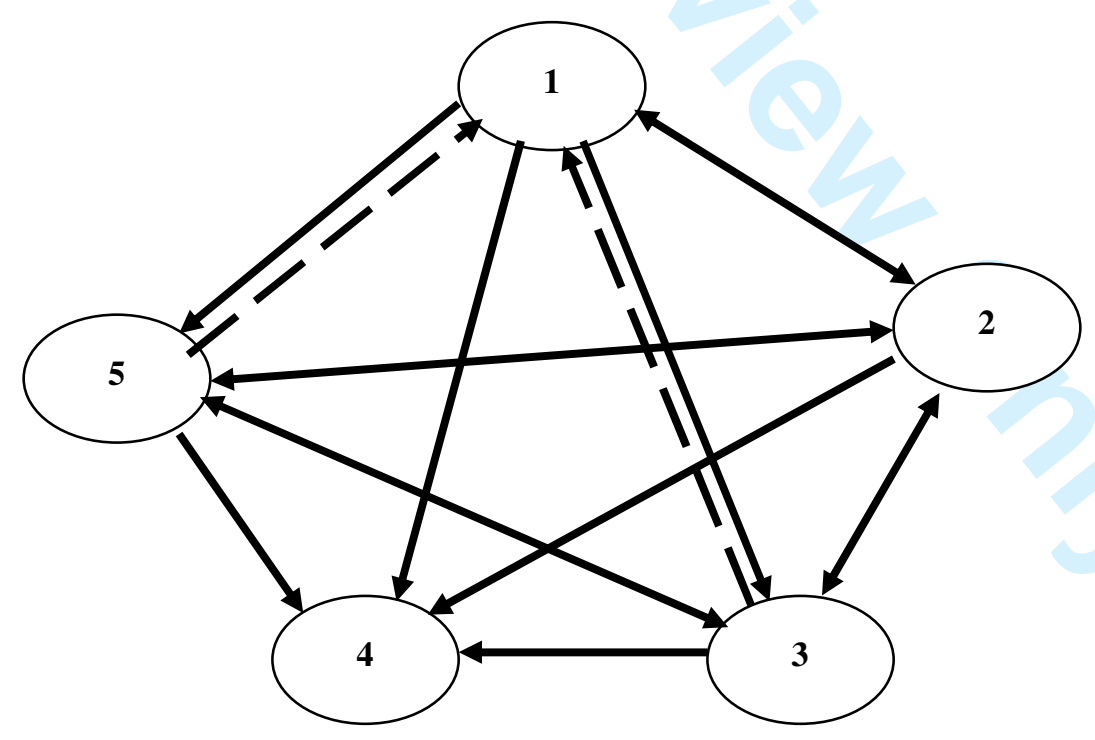

Figure 5: Final diagraph for the risks 


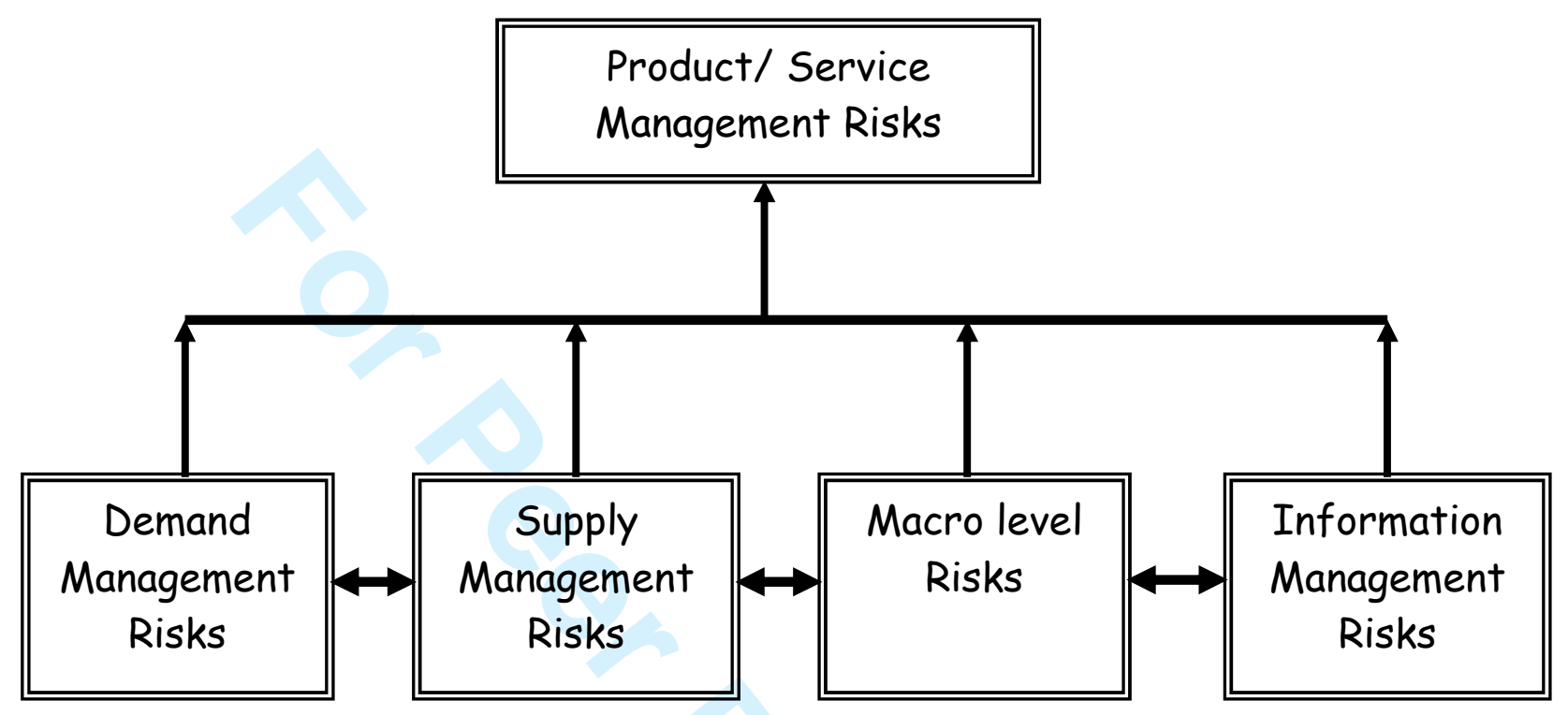

Figure 6: Model for the food supply chain risks of the firm 
1

2

3

4

5

6

7

8

9

10

11

12

13

14

15

16

17

18

19

20

21

22

23

24

25

26

27

28

29

30

31

32

33

34

35

36

37

38

39

40

41

42

43

44

45

46

47

48

49

50

51

52

53

54

55

56

57

58

59

60
อ

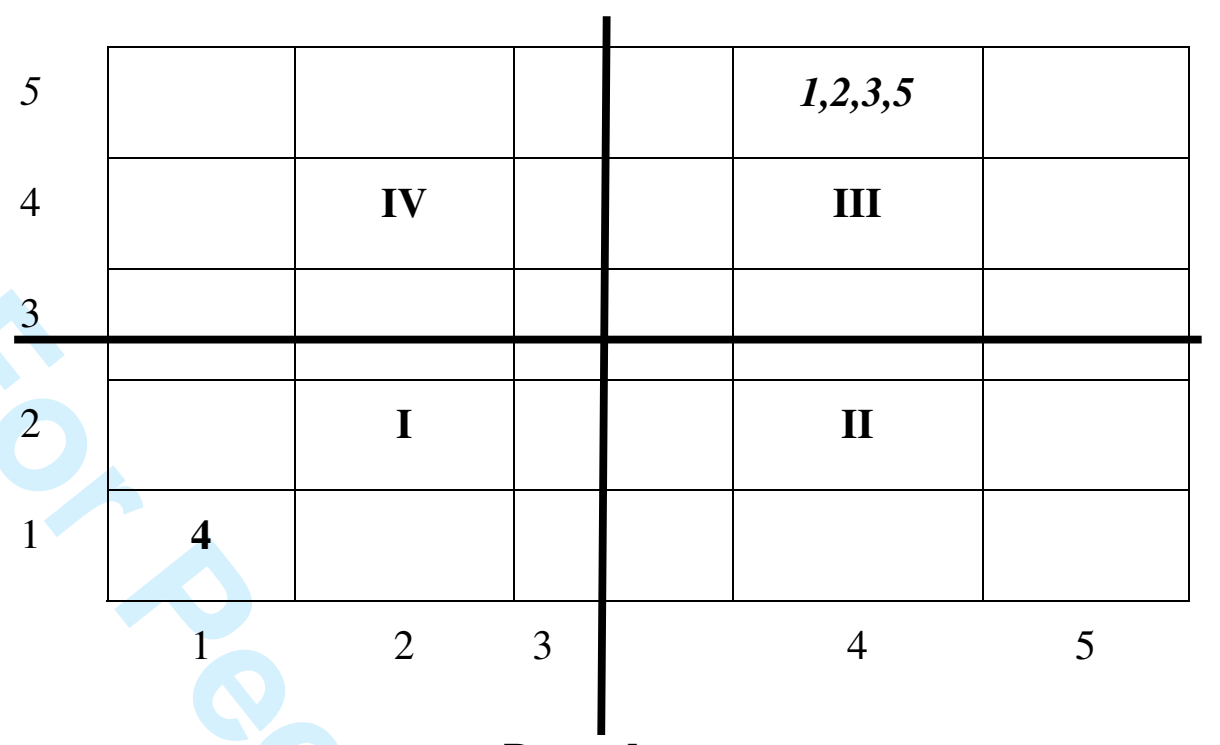

Dependence power

Figure 7: Driving power and dependence power diagram 


\section{TABLES:}

Table 1: Applications of ISM methodology

\begin{tabular}{|c|l|l|}
\hline Year & \multicolumn{1}{|c|}{ Author } & Application \\
\hline 1975 & Hawthorne and Sage & Higher education program planning \\
\hline 1977 & Sage & $\begin{array}{l}\text { Modelling on complex situations presented by } \\
\text { large systems }\end{array}$ \\
\hline 1980 & Jedlicka and Meyer & $\begin{array}{l}\text { Exploring factors involved in a cross-cultural } \\
\text { context }\end{array}$ \\
\hline 1992 & Saxena et al. & $\begin{array}{l}\text { Determining the hierarchy and class of elements in } \\
\text { cement industry }\end{array}$ \\
\hline 1993 & Mandal and Deshmukh & Vendor selection in supply chain \\
\hline 1999 & Kanungo et al. & $\begin{array}{l}\text { To develop an information system effectiveness } \\
\text { framework }\end{array}$ \\
\hline 2004 & Ravi and Shankar & Barriers of reverse logistics \\
\hline 2005 & Jharkaria and Shankar & Enablers of IT implementation in supply chain \\
\hline 2005 & Ravi et al. & Identifying key reverse logistic variables \\
\hline 2006 & Faisal et al. & $\begin{array}{l}\text { Modelling the enablers for supply chain risk } \\
\text { mitigation }\end{array}$ \\
\hline 2006 & Thakkar et al. & $\begin{array}{l}\text { Integrated approach with ISM and ANP to develop } \\
\text { a balanced score card }\end{array}$ \\
\hline
\end{tabular}


Table 2: Summary of various risks and mitigation strategies

\begin{tabular}{|c|c|c|}
\hline Risk category & Risk type & Mitigation strategy \\
\hline $\begin{array}{l}\text { Macro level } \\
\text { risks }\end{array}$ & $\begin{array}{l}\text { 1. Natural disaster } \\
\text { 2. Diseases like bird flu } \\
\text { 3. Political unrest } \\
\text { 4. Terrorist attacks } \\
\text { 5. Government regulation } \\
\text { 6. Labour strikes } \\
\text { 7. Lack of skilled personnel }\end{array}$ & $\begin{array}{l}\text { Identify vulnerability points and have } \\
\text { contingency plans } \\
\text { Lobbying } \\
\text { Always support a participative style of } \\
\text { management }\end{array}$ \\
\hline $\begin{array}{l}\text { Demand } \\
\text { management } \\
\text { risks }\end{array}$ & $\begin{array}{l}\text { 1. Sudden loss of demand } \\
\text { due to economic } \\
\text { downturn } \\
\text { 2. Volatile demand } \\
\text { 3. Changes in customer } \\
\text { tastes } \\
\text { 4. Failure to communicate } \\
\text { with customers }\end{array}$ & $\begin{array}{l}\text { Cost reduction in operations } \\
\text { Cost reduction in operations; manage demand } \\
\text { through promotions and incentives to customers; } \\
\text { assistance from professionally qualified agencies } \\
\text { Manage demand through promotions and } \\
\text { incentives to customers; work to incorporate } \\
\text { changes in customer tastes; assistance from } \\
\text { professionally qualified agencies } \\
\text { Better planning and coordination of supply and } \\
\text { demand; identify vulnerability points and have } \\
\text { contingency plans; invest in good } \\
\text { communications infrastructure }\end{array}$ \\
\hline $\begin{array}{l}\text { Supply } \\
\text { Management } \\
\text { Risks }\end{array}$ & $\begin{array}{l}\text { 1. Supplier bankruptcy } \\
\text { 2. Communication failure } \\
\text { 3. Failure of the partnership } \\
\text { 4. Poor quality of the } \\
\text { supplied goods } \\
\text { 5. Inability of supply }\end{array}$ & $\begin{array}{l}\text { Multiple sourcing strategy; supplier evaluation } \\
\text { and selection } \\
\text { Multiple sourcing strategy } \\
\text { Multiple sourcing strategy; Strengthen and build } \\
\text { trust with suppliers } \\
\text { Better planning and coordination with suppliers; } \\
\text { multiple sourcing strategy; flexible capacity; } \\
\text { multiple sourcing strategy; supplier development } \\
\text { programme }\end{array}$ \\
\hline $\begin{array}{l}\text { Product/Service } \\
\text { Management } \\
\text { Risks }\end{array}$ & $\begin{array}{l}\text { 1. Excessive inventory } \\
\text { 2. Underutilised capacity }\end{array}$ & $\begin{array}{l}\text { Better planning and coordination of supply and } \\
\text { demand; flexible capacity } \\
\text { Better planning of capacity requirements }\end{array}$ \\
\hline $\begin{array}{l}\text { Information } \\
\text { Management } \\
\text { Risks }\end{array}$ & $\begin{array}{l}\text { 2. Distortions in } \\
\text { information sharing } \\
\text { 3. Failure in IT systems }\end{array}$ & $\begin{array}{l}\text { Better planning and coordination of supply and } \\
\text { demand; investment in good communications } \\
\text { infrastructure } \\
\text { Identify vulnerability points and have } \\
\text { contingency plans }\end{array}$ \\
\hline
\end{tabular}


Table 3: Structural Self-Interaction Matrix for the risks in the food supply chain

\begin{tabular}{|l|c|c|c|c|c|}
\hline & $\begin{array}{c}\text { Information } \\
\text { Management } \\
\text { Risk } \\
(5)\end{array}$ & $\begin{array}{c}\text { Product/ Service } \\
\text { Management } \\
\text { Risk } \\
(4)\end{array}$ & $\begin{array}{c}\text { Supply } \\
\text { Management } \\
\text { Risk } \\
(3)\end{array}$ & $\begin{array}{c}\text { Demand } \\
\text { Management } \\
\text { Risk } \\
(2)\end{array}$ & $\begin{array}{c}\text { Macro } \\
\text { level } \\
\text { Risk } \\
(1)\end{array}$ \\
\hline Macro level Risk (1) & $\mathrm{V}$ & $\mathrm{V}$ & $\mathrm{V}$ & $\mathrm{X}$ & - \\
\hline $\begin{array}{l}\text { Demand } \\
\text { Management Risk (2) }\end{array}$ & $\mathrm{X}$ & $\mathrm{V}$ & $\mathrm{X}$ & - & - \\
\hline $\begin{array}{l}\text { Supply } \\
\text { Management Risk (3) }\end{array}$ & $\mathrm{X}$ & $\mathrm{V}$ & - & - & - \\
\hline $\begin{array}{l}\text { Product/Service } \\
\text { Management Risk (4) }\end{array}$ & $\mathrm{A}$ & - & - & - & - \\
\hline $\begin{array}{l}\text { Information } \\
\text { Management Risk (5) }\end{array}$ & - & - & - & - & - \\
\hline
\end{tabular}

Table 3a: Initial reachability matrix for the risks in the food supply chain of the firm

\begin{tabular}{|l|l|l|l|l|l|l|}
\hline & 1 & 2 & 3 & 4 & 5 & Driver power \\
\hline 1 & 1 & 1 & 1 & 1 & 1 & 5 \\
\hline 2 & 1 & 1 & 1 & 1 & 1 & 5 \\
\hline 3 & 0 & 1 & 1 & 1 & 1 & 4 \\
\hline 4 & 0 & 0 & 0 & 1 & 0 & 1 \\
\hline 5 & 0 & 1 & 1 & 1 & 1 & 4 \\
\hline Dependence power & 2 & 4 & 4 & 5 & 4 & \\
\hline
\end{tabular}

Table 3b: Final reachability matrix for the risks in the food supply chain of the firm

\begin{tabular}{|c|c|c|c|c|c|c|}
\hline & 1 & 2 & 3 & 4 & 5 & $\begin{array}{c}\text { Driver } \\
\text { power }\end{array}$ \\
\hline 1 & 1 & 1 & 1 & 1 & 1 & 5 \\
\hline 2 & 1 & 1 & 1 & 1 & 1 & 5 \\
\hline 3 & 1 & 1 & 1 & 1 & 1 & 5 \\
\hline 4 & 0 & 0 & 0 & 1 & 0 & 1 \\
\hline 5 & 1 & 1 & 1 & 1 & 1 & 5 \\
\hline Dependence power & 4 & 4 & 4 & 5 & 4 & \\
\hline
\end{tabular}


Table 4a: Level partition of risks - Iteration 1

\begin{tabular}{|l|c|c|c|c|}
\hline \multicolumn{1}{|c|}{ Risks } & $\begin{array}{c}\text { Reachability } \\
\text { set }\end{array}$ & Antecedent set & Intersection & Level \\
\hline Macro level risk & 12345 & 1235 & 1235 & \\
\hline Demand management risk & 12345 & 1235 & 1235 & \\
\hline Supply management risk & 12345 & 1235 & 1235 & \\
\hline Product/ service management risk & 4 & 12345 & 4 & I \\
\hline Information management risk & 12345 & 1235 & 1235 & \\
\hline
\end{tabular}

Table 4b: Level partition of risks - Iteration 2

\begin{tabular}{|l|c|c|c|c|}
\hline \multicolumn{1}{|c|}{ Risks } & Reachability set & Antecedent set & Intersection & Level \\
\hline Macro level risk & 1235 & 1235 & 1235 & II \\
\hline Demand management risk & 1235 & 1235 & 1235 & II \\
\hline Supply management risk & 1235 & 1235 & 1235 & II \\
\hline Information management risk & 1235 & 1235 & 1235 & II \\
\hline
\end{tabular}

